\title{
DAS WAPPEN \\ IN KUNST UND GEWERBE
}




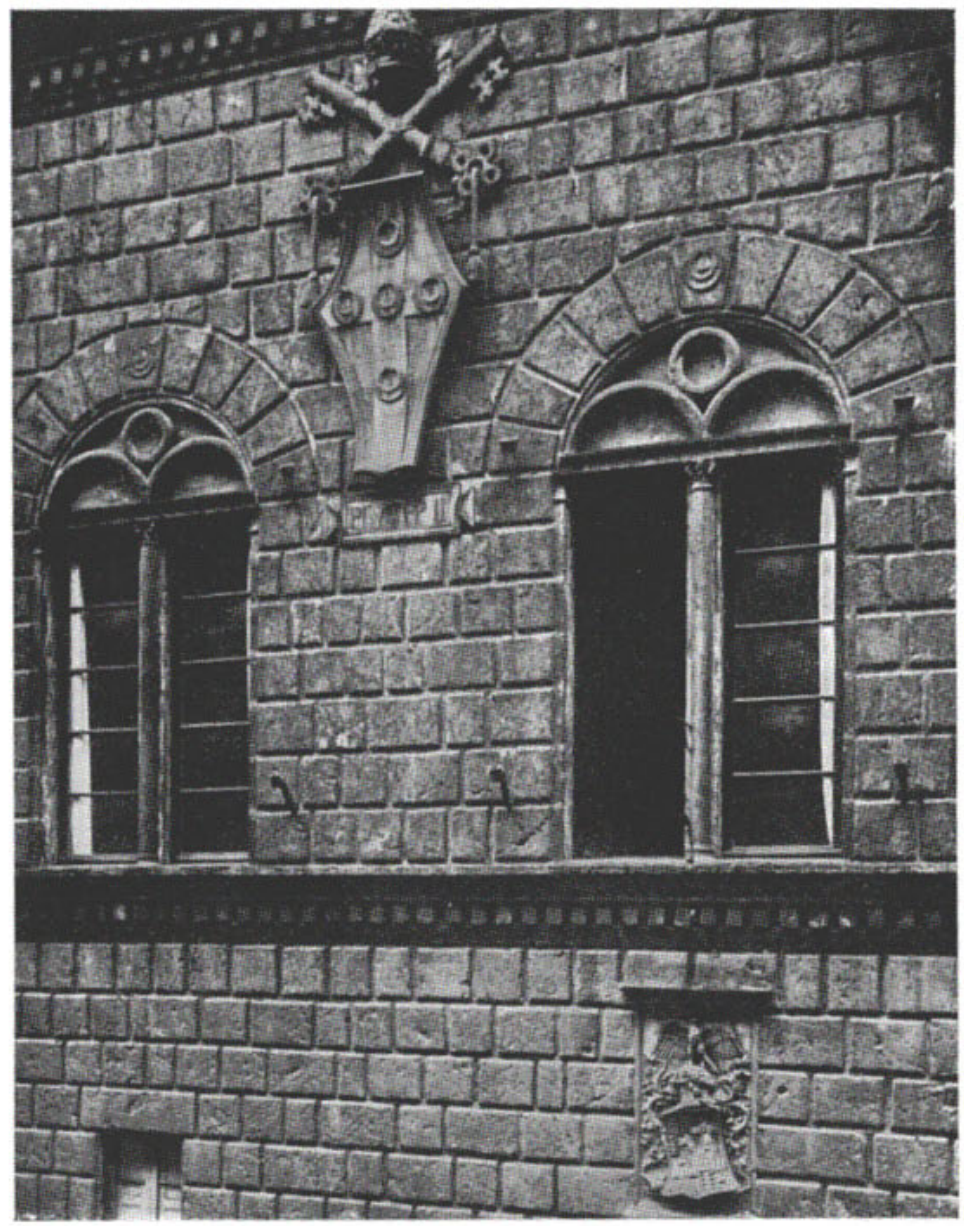

Palastfassade mit Wappenschmuck. Slena. (Phot. Alinari.) 


\title{
DAS WAPPEN
}

\section{IN KUNST UND GEWERBE}

\author{
VON \\ E. A. STUCKELBERG
}

MIT 214 ABBILDUNGEN

ZWEITE AUFLAGE

LEIPZIG

VERLAG VON VEIT \& COMP. 
